\title{
RESEARCH ON THE QUALITY ASSURANCE OF FRESH COW'S CHEESE WITH ADDITION OF PROBIOTICS
}

\author{
Maria Adelina, Constantinescu ${ }^{1}$ and Mihaela Adriana, Titạ ${ }^{2}$ \\ 1,Lucian Blaga" University of Sibiu, Romania, constantinescumariaadelina@yahoo.com \\ 2"Lucian Blaga" University of Sibiu, Romania, mihaela.tita@ulbsibiu.ro
}

\begin{abstract}
Fresh cow's cheese is a unfermented product obtained from cow's milk. Probiotics are microorganisms which are believed to offers benefits for health when are consumed. The objective of the research is to identify the hazards, to assess the risks and to establish the critical control points from the technological flow of obtaining fresh cow cheese with addition of probiotics.
\end{abstract}

KEY WORDS: cheese, probiotics, quality, hazards

\section{INTRODUCTION}

Fresh cheeses are obtained by coagulating milk or whey and are ready for consumption immediately after preparation. The quality of fresh cheeses is influenced by numerous parameters, including gel structure, whey separation conditions and coagulation treatments [1]. The standards in force require that fresh cow's cheese to correspond to some sensory, chemical and microbiological indices. It must be a fine and creamy paste, white to slightly yellowish color, with a pleasant, aromatic and sour flavor, specific to the lactic fermentation. The fat content should be between 0 and $40 \%$, depending on the assortment to be processed, the acidity not to exceed $90^{\circ} \mathrm{T}$, and the pasteurisation control reaction must be negative. Pathogenic germs should be absent and coliform bacteria present at maximum $20 / \mathrm{cm}^{2}$ [2].

Probiotics are defined as live microbial food supplements that bring benefit for health if they are consumed [3]. A microorganism that is considered probiotic must survive until it reaches in the stomach and maintain viability and metabolic activity in the intestine [4]. Probiotics have undergone research to find out if they really have beneficial effects on the health of the consumer. These researches concerned diseases such as allergies, diarrhea associated with antibiotics, high blood pressure, cholesterol, eczema, Helicobacter pylori infections, low immunity, inflamed and irritated intestine, lactose intolerance [5]. Probiotics used to obtain the product are: Lactobacillus acidophilus, Bifidobacterium infantis, Enterococcus faecium.

Because probiotic bacteria require more special processing conditions, the qualitative analysis tools used in this study are the $5 \mathrm{M}$ (Ishikawa) diagram to determine the causes that lead to the emergence of hazards, the risk class matrix and the SWOT analysis. With the help of the risk matrix, fit each hazard emerges in a risk class based on severity and frequency. The higher the risk class, the more this danger can become a critical control point. For each critical control point are applied corrective actions so that it is kept within certain limits. The
SWOT analysis helps identify strengths and weaknesses of the product and also the market opportunities and threats.

\section{METHODS}

\subsection{Risk Matrix}

Hazard identification consists in determining the biological, chemical and physical agents that may pose a significant hazard. Risk assessment is the indication of the frequency or probability of occurrence of each identified hazard and the indication of the severity of the hazard [6]. The risk assessment is done using the hazard matrix.

Table 1. Matrix for identifying risk classes.

\begin{tabular}{|c|c|c|c|}
\hline $\mathbf{G}$ & \multicolumn{3}{|c|}{$\boldsymbol{R C}$} \\
\hline $\boldsymbol{H}$ & 3 & 4 & 4 \\
\hline $\boldsymbol{M}$ & 2 & 3 & 4 \\
\hline $\boldsymbol{L}$ & 1 & 2 & 3 \\
\hline $\boldsymbol{F}$ & $\boldsymbol{L}$ & $\boldsymbol{M}$ & $\boldsymbol{R}$ \\
\hline
\end{tabular}

$\mathrm{RC}$ - risk classes; $\mathrm{G}$ - gravity; $\mathrm{F}$ - frequency; $\mathrm{H}$ - high; $\mathrm{M}$ medium; L - low

\subsection{Ishikawa diagram}

The Ishikawa diagram ( $5 \mathrm{M}$, fishbone, cause - effect ) is a tool that identifies the basic causes for all quality problems. This is a correlation between an effect and its multiple causes of production. It has the shape of a fish bone and its representation consists of 5 oblique segments that lean on a horizontal axis. This diagram illustrates the main and secondary causes of a particular effect [7].

\subsection{CCP identification: Critical control points}

A critical control point is a procedure, a stage or an operation that, if not kept under control, generates an unacceptable risk that has no possibility of subsequent correction. For each critical control point, it is necessary to determine the ways and methods to ensure that critical limits are not exceeded [6]. 


\subsection{SWOT analysis}

It is an internal review of an organization about strengths and weaknesses, its growth opportunities, and the threats that exist in the external environment that affects its survival. Strengths are high-level features that a product possesses compared to other products. Weaknesses are factors that affect the quality of the product. Opportunities are the factors that help to development of product. Threats are factors that have negative effects on the product [8].

\section{RESULTS AND DISCUSSIONS}

Causes are the factors that lead to worsening of danger [6]. To better identify the causes, we used the Ishikawa diagram.

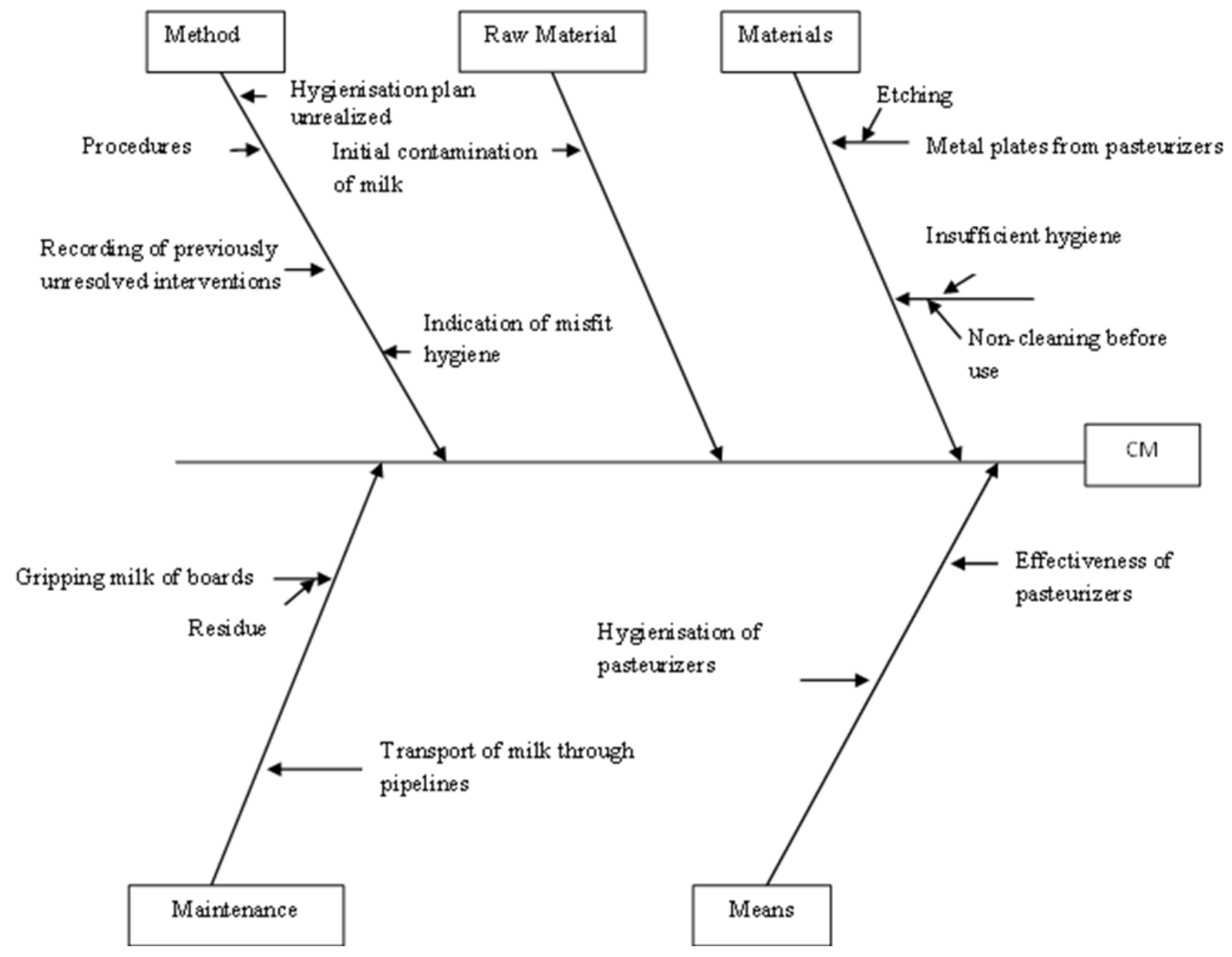

Figure 1. Ishikawa diagram

The main causes that lead to the emergence of hazards are related to the method, which includes the procedure, the failure contamination of milk, of materials due to the corresponding non-cleaning of the pasteurizers, of maintenance and means. to complete the hygiene plan, of raw material due to the initial

Table 2. Hazard identification

\begin{tabular}{|c|c|c|c|c|}
\hline Number & Stage of the process & $\begin{array}{c}\text { Potential physical, } \\
\text { chemical, microbiological } \\
\text { risks }\end{array}$ & Causes & Preventive measures \\
\hline \multirow{3}{*}{1.} & \multirow{3}{*}{$\begin{array}{l}\text { Qualitative and } \\
\text { quantitative } \\
\text { reception }\end{array}$} & Microbiological & $\begin{array}{l}\text { Pathogenic bacteria: } \\
\text { Staphylococcus aureus }\end{array}$ & $\begin{array}{c}\text { Supplier selection } \\
\text { Sanitary certificate, analysis bulletin } \\
\text { Good hygiene practices } \\
\text { Staff training }\end{array}$ \\
\hline & & Chemical & Antibiotics & $\begin{array}{c}\text { Supplier selection } \\
\text { Analysis bulletin } \\
\text { Sanitary veterinary certificate } \\
\end{array}$ \\
\hline & & Physical & Plastic, glass, stones & $\begin{array}{l}\text { Good hygiene practices } \\
\text { Supplier selection } \\
\text { Staff training }\end{array}$ \\
\hline
\end{tabular}




\begin{tabular}{|c|c|c|c|c|}
\hline Number & Stage of the process & $\begin{array}{c}\text { Potential physical, } \\
\text { chemical, microbiological } \\
\text { risks }\end{array}$ & Causes & Preventive measures \\
\hline 2. & Pasteurization & Microbiological & $\begin{array}{l}\text { Pathogenic bacteria: } \\
\text { Mycobacterium } \\
\text { tuberculosis }\end{array}$ & $\begin{array}{c}\text { Good hygiene and production } \\
\text { practices (GHP-GMP) } \\
\text { Respect the regime of pasteurization } \\
\text { Staff training } \\
\text { Equipment maintenance }\end{array}$ \\
\hline \multirow[b]{2}{*}{3.} & \multirow[b]{2}{*}{$\begin{array}{l}\text { Cooling for } \\
\text { thermostats }\end{array}$} & Microbiological & Mold: Aspergillus & $\begin{array}{c}\text { Good hygiene practices } \\
\text { Intermediate milk storage below 4-6 } \\
{ }^{\circ} \mathrm{C} \text {, max. } 24 \mathrm{~h} \\
\text { Microbiological tests } \\
\end{array}$ \\
\hline & & Chemical & $\begin{array}{c}\text { Detergents } \\
\text { Cooling agent }\end{array}$ & $\begin{array}{c}\text { Staff training } \\
\text { Good hygiene and production } \\
\text { practices } \\
\text { Tests, } p H \\
\text { Equipment maintenance }\end{array}$ \\
\hline 4. & Sowing (maturing) & Chemical & $\begin{array}{l}\text { Detergents } \\
\text { Cooling agent }\end{array}$ & $\begin{array}{c}\text { Staff training } \\
\text { Good hygiene and production } \\
\text { practices } \\
\text { Tests, pH } \\
\text { Equipment maintenance }\end{array}$ \\
\hline \multirow[t]{2}{*}{5.} & \multirow{2}{*}{$\begin{array}{l}\text { Packaging and } \\
\text { Storage }\end{array}$} & Microbiological & Coliform bacteria & $\begin{array}{c}\text { GHP, GMP } \\
\text { Monitor the average parameters } \\
\text { Staff training }\end{array}$ \\
\hline & & Physical & Foreign bodies & $\begin{array}{c}G H P, G M P \\
\text { Staff training }\end{array}$ \\
\hline
\end{tabular}

Depending on the hazards found and using the risk class identification matrix, we assigned each hazard to a risk class, depending on gravity and frequency.

Table 3. Stages of technological process, type of danger and risk class

\begin{tabular}{|c|c|c|c|c|}
\hline Steps & Type hazards & Gravity & Frequency & Risk Class \\
\hline \multirow{3}{*}{$\begin{array}{c}\text { Qualitative and } \\
\text { quantitative reception }\end{array}$} & Microbiological & $H$ & $L$ & 3 \\
\hline & Chemical & $M$ & $M$ & 3 \\
\hline & Physical & $M$ & $L$ & 2 \\
\hline \multirow{2}{*}{ Cooling for thermostats } & Microbiological & $M$ & $M$ & 3 \\
\hline & Chemical & $M$ & $M$ & 3 \\
\hline Sowing (maturing) & Chemical & $M$ & $M$ & 3 \\
\hline Packaging and Storage & Physical & $M$ & $L$ & 2 \\
\hline
\end{tabular}

Risk class:

1- Theoretically

2- We intervene through staff awareness procedures

3- General control procedures, supports a CP

Table 4. Identification of critical control points

\begin{tabular}{|c|c|c|c|}
\hline Steps & Identified hazard & Risk class & CCP/CP \\
\hline \multirow{2}{*}{$\begin{array}{c}\text { Qualitative and quantitative } \\
\text { reception }\end{array}$} & Microbiological & 3 & $C P 1$ \\
\cline { 2 - 4 } & Chemical & 3 & $C P 2$ \\
\hline Pasteurization & Microbiological & 4 & $C P 1$ \\
\hline \multirow{2}{*}{ Cooling for thermostats } & Microbiological & 3 & $C P 3$ \\
\cline { 2 - 4 } & Chemical & 3 & $C P 4$ \\
\hline Sowing (maturing) & Chemical & 3 & $C P 5$ \\
\hline Packaging and Storage & Microbiological & 4 & $C P 2$ \\
\hline
\end{tabular}

Critical control points are for pasteurization and packaging and storage. In order to keep these CCP within certain limits, corrective actions need to be identified.
4- Specific control procedures, supports a CCP

Depending on the risk class, critical control points were identified. 
Table 5. Corrective actions

\begin{tabular}{|c|c|c|c|c|c|c|}
\hline Steps & CCP & Causes & Preventive actions & Critical limits & Surveillance methods & Corrective actions \\
\hline Pasteurization & CCP1 & $\begin{array}{c}\text { Ready } \\
\text { reckoner } \\
\text { thermal } \\
\text { insufficiency }\end{array}$ & $\begin{array}{c}\text { Ready reckoner } \\
\text { control }\end{array}$ & $\begin{array}{c}90^{\circ} \text { C,5-6 } \\
\text { minutes }\end{array}$ & $\begin{array}{c}\text { Measuring output } \\
\text { temperature } \\
\text { Check the } \\
\text { pasteurization time }\end{array}$ & $\begin{array}{c}\text { Milk recirculation } \\
\text { Machine setting } \\
\text { Staff training }\end{array}$ \\
\hline $\begin{array}{c}\text { Packaging } \\
\text { and Storage }\end{array}$ & CCP2 & $\begin{array}{c}\text { High } \\
\text { temperature }\end{array}$ & $\begin{array}{c}\text { Temperature } \\
\text { control }\end{array}$ & $\mathrm{T}=5^{\circ} \mathrm{C}$ & $\begin{array}{c}\text { Temperature } \\
\text { measurement }\end{array}$ & $\begin{array}{c}\text { Adjusting } \\
\text { temperature }\end{array}$ \\
\hline
\end{tabular}

For a product it is very important to know its strengths and weaknesses compared to other products, but also development

opportunities and threats are very important to know. For this reason, it is very necessary to carry out a SWOT analysis.

\begin{tabular}{|c|c|}
\hline \multicolumn{2}{|c|}{ STOT diagram } \\
\hline $\begin{array}{c}\text { Strengths } \\
\text { - health benefits; } \\
\text { - the quality of raw materials and } \\
\text { finished products; }\end{array}$ & $\begin{array}{c}\text { Weaknesses } \\
\text { - some people have lactose } \\
\text { intolerance; } \\
\text { - lack of product diversity, } \\
\text { - high price of the finished } \\
\text { product; }\end{array}$ \\
\hline $\begin{array}{c}\text { Opportunities } \\
\text { - consumers' interest for a healthy diet; } \\
\text { - the possibility of developing new } \\
\text { products and a ttracting new } \\
\text { customers; }\end{array}$ & $\begin{array}{c}\text { Threats } \\
\text { - the rising cost of raw materials } \\
\text { - changes in customer } \\
\text { requirements, tastes or } \\
\text { preferences }\end{array}$ \\
\hline
\end{tabular}

Figure 2. SWOT Diagram

From what can be seen the most important advantage of the fresh cow's cheese with probiotics is the health benefit, but also the quality of the raw materials used is equally important. The intolerance presented by certain people to lactose and the high price of the finished product are the weaknesses of the product.

An important opportunity to develop the sales market is the growing interest of consumers for a healthy diet. Market threats are the rising cost of raw materials, which leads to an increase in the price of the finished product and changes in customer requirements, tastes and preferences, which leads to a decrease in production.

\section{CONCLUSION}

Fresh cow's cheese with probiotics is a dairy product that brings a true health benefit that can be consumed from the first year of life. Identifying the root causes is done using the Ishikawa diagram and helps avoid the emergence of hazards. The emerging hazards can be for three types: microbiological, chemical and physical. Depending on gravity and frequency, they fall into a risk class and then critical control points are established. It is important for each critical control point to take corrective actions, so as to be kept within certain limits.

SWOT analysis is beneficial to characterize a product. So we can see what our product has in addition to others, that is the strengths, but also what we need to improve, that is, the weaknesses. You have to take advantage of what the market offers you, that is opportunities and control threats.

\section{REFERENCES}

1. Fox, Patrick F., Timothy P. Guinee, Timothy M. Cogan, and Paul L. H. McSweeney. Fundamentals of Cheese Science. Boston: Springer, Boston, MA, p. 543-588, (2016)

2. Costin, G.M., and Rodica Segal. Alimente funcționale. Galați: Ed. Academică, p.145, (1999)

3. Songisepp, E.; Kullisaar, T.; Hutt, P.; Elias, P.; Brilene, T.; Zilmer, M.; Mikelsaar, M. A new probiotic cheese with antioxidative and antimicrobial activity. Tartu: American Dairy Science Association, (2004).

4. Araújo, Emiliane Andrade, Ana Clarissa dos Santos Pires, Maximiliano Soares Pinto, Gwénaël Jan, and Antônio Fernandes Carvalho. Probiotics in Dairy Fermented Products. Rennes: CC BY 3.0 license., p.129-148, (2012)

5. Salminen, Seppo, and Henk Loveren. Probiotics and prebiotics: health claim substantiation. (2012).

6. Bratu, Iuliana. HACCP de la teorie - la practică. Sibiu: Editura Universității "Lucian Blaga" din Sibiu, p. 35, 39$45,(2002)$

7. Ilie, Gheorghe, and Carmen Nadia Ciocoiu. Application of fishbone diagram to determine the risk of an event with multiple causes. București, (2010).

8. Gretzky, Wayne. Strategic planning and SWOT analysis. (2010). 